日植病報 $49: 633-638$ (1983)

Ann. Phytopath. Soc. Japan 49: 633-638 (1983)

\title{
Cleavage of Replicative Form DNAs of Filamentous Phages Xf and Xf 2 by Restriction Endonucleases*
}

\author{
Hiroshi Kamiunten** and Satiosh Wakimoto** \\ 上運天＼cjkstart博**・脇本 哲**：緘維状ファージ Xf 拈よび Xf 2 \\ の複製型 DNA の制限酵素による切断*
}

\begin{abstract}
Two filamentous phages of Xanthomonas campestris pv. oryzae, Xf and Xf 2, are almost similar in DNA base composition. To investigate the degree of homology between $\mathrm{Xf}$ and $\mathrm{Xf} 2$ more in detail, the cleavage patterns of their replicative form DNA (RFI-DNA) treated with restriction endonucleases were compared by means of polyacrylamide gel electrophoresis. RFI-DNA was prepared by ethanol-precipitation method from the lysate of phage infected-bacteria. DNAs of Xf-RFI and Xf 2-RFI thus obtained had infectivity to $X$. campestris pv. oryzae and their molecular weights were estimated at $4.5 \times 10^{6}$ and $4.7 \times 10^{6}$ daltons, respectively, from their relative mobilities. Both RFI-DNAs were treated with endo R. Hpa II, Hha I, Hind II, Hae III and Alu I to be subjected to the electrophoresis. Since most of the cleavage products of both RFI-DNAs showed remarkable difference in electrophoresis patterns, the phages Xf and Xf 2 were considered to be heterogeneous.
\end{abstract}

(Received May 1, 1983)

Key Words: Xanthomonas campestris pv. oryzae, filamentous phage, cleavage pattern.

\section{Introduction}

Two filamentous phages, $\mathrm{Xf}$ and $\mathrm{Xf} 2$, isolated from culture fluids of Xanthomonas campestris pv. oryzae isolates ${ }^{7,13)}$ are known to be different from each other in particle length, serological characteristics and host range $^{7)}$. In the base ratio of DNAs, however, these phages were resembled each other ${ }^{8)}$.

Van den Hondel and Schoenmakers ${ }^{11)}$ reported that digestion of phage DNA with restriction enzyme followed by polyacrylamide gel electrophoresis was a new and powerful method for identification of filamentous coliphages.

In this study, the replicative form DNAs of Xf and Xf 2 (Xf-RFI and Xf 2-RFI) were isolated from the bacteria infected with respective phages, and gel electrophoresis patterns of the products obtained by the treatment with restriction endonucleases were compared.

\section{Materials}

Bacteria, phages and plasmids. X. campestris pv. oryzae N5850 and filamentous phages Xf and Xf 2 were used throughout this experiment. Plasmids pBR 322, pBR

* Supported in part by a Grant-in-Aid from Ministry of Education, Science and Culture of Japan (No. 58560049).

** Faculty of Agriculture, Kyushu University, Fukuoka 812, Japan九州大学農学部 
325 and pBR 322G were furnished by Dr. T. Miki, Faculty of Pharmaceutical Sciences, Kyushu University.

Restriction endonuclease. Endo R. Hpa II, Hha I, Hae III and Alu I were purchased from Bethesda Research Laboratories, Inc. and Hind II from Takara Shuzo Co. LTD..

Medium. Bacteria were grown in PS medium ${ }^{12}$ (decoction of $300 \mathrm{~g}$ potato 1 liter, $\mathrm{Na}_{2} \mathrm{HPO}_{4} \cdot 12 \mathrm{H}_{2} \mathrm{O} 2 \mathrm{~g}, \mathrm{Ca}\left(\mathrm{NO}_{3}\right)_{2} \cdot 4 \mathrm{H}_{2} \mathrm{O} 0.5 \mathrm{~g}$, pepton $5 \mathrm{~g}$, sucrose $20 \mathrm{~g}, \mathrm{pH} 7.0$ ). For plaque formation, the same medium supplied with agar at a concentration of $0.6 \%$ was employed.

\section{Methods, Results and Discussion}

\section{Isolation of replicative form DNA}

$X$. campestris pv. oryzae N5850 was grown in PS medium at $30 \mathrm{C}$. When the bacterial concentration reached about $10^{7}$ cells $/ \mathrm{ml}$, the bacteria were infected with the filamentous phage at a multiplicity of 50-100. After shaking at $30 \mathrm{C}$ for $15 \mathrm{hr}$, chloramphenicol was added to give a concentration of $30 \mu \mathrm{g} / \mathrm{ml}$ and incubated at $30 \mathrm{C}$ for $2 \mathrm{hr}$. The bacteria were collected by centrifugation at $8,000 \times g$ for $10 \mathrm{~min}$ and washed two times with TES buffer $(0.05 \mathrm{M}$ Tris, $0.005 \mathrm{M}$ EDTA, $0.05 \mathrm{M} \mathrm{NaCl}, \mathrm{pH}$ 8.0). The cell lysis and removal of chromosomal DNA from the lysate was performed by the following two different methods.

(A) Modified Clewell and Helinski's method ${ }^{2,9)}$ : The bacteria harvested from $200 \mathrm{ml}$ of PS medium were washed by centrifugation and resuspended in $10 \mathrm{ml}$ of cold $25 \%$ sucrose in $0.05 \mathrm{M}$ Tris ( $\mathrm{pH} 8.0$ ), RNase was added at a final concentration of $50 \mu \mathrm{l} / \mathrm{ml}$, lysozyme ( $1 \mathrm{ml}$ of $1 \%$ lysozyme solution in $0.25 \mathrm{M}$ Tris, $\mathrm{pH} 8.0$ ) was added, mixed gently, and iced for $5 \mathrm{~min}$. Two $\mathrm{ml}$ of EDTA solution (0.25 M, pH 8.0) was added to the mixture and kept at $0 \mathrm{C}$ for $10 \mathrm{~min}$. Sixteen $\mathrm{ml}$ of cold Triton lytic mixture ( $1 \%$ Triton $\mathrm{X}-100,0.0626 \mathrm{M}$ EDTA, 0.05 M Tris, $\mathrm{pH} 8.0$ ) was then added slowly. The bacterial suspension remained turbid even after $30 \mathrm{~min}$. Additional overnight incubation at $4 \mathrm{C}$ did not show any efficacy for clarification. The lysate was centrifuged at $15,000 \times \mathrm{g}$ for $30 \mathrm{~min}$ and supernatant was used for further experiment.

(B) Modified Comai and Kosuge's method ${ }^{32}$ : The washed bacteria were resuspended in minimal volume of TE buffer (0.05 M Tris, 0.02 M EDTA, pH 8.0 $)^{1)}$. 0.4 volume of lysing buffer (TE buffer containing $3 \%$ sodium dodecyl sulphate, $\mathrm{pH} 12.45$ ) was then added to the bacterial suspension and mixed gently. The mixture was incubated at $50 \mathrm{C}$ for 45 to $60 \mathrm{~min}$ until it became clear. The $\mathrm{pH}$ was then lowered to 8.0 to 9.0 by adding $2 \mathrm{M}$ Tris ( $\mathrm{pH} 5.5$ ), and $5 \mathrm{M} \mathrm{NaCl}$ solution was added to adjust final concentration at $1 \mathrm{M}$. After icing for $2 \mathrm{hr}$, the lysate was centrifuged at $15,000 \times \mathrm{g}$ for $30 \mathrm{~min}$ and its supernatant was used.

Concentration and precipitation of phage DNA from the lysate prepared by the above methods were done as follows.

Polyethylene glycol $6000^{6}$ ) was added to the supernatant at final concentration of $10 \%$, and incubated at $0 \mathrm{C}$ for $2 \mathrm{hr}$. After centrifugation $(7,000 \times g, 20 \mathrm{~min})$, the precipitate was resuspended in a minimal volume of TES buffer. An equal volume of phenol saturated with an aqueous solution containing $3 \% \mathrm{NaCl}^{4}$ ) was added, mixed 
gently and centrifuged at $7,000 \times g$ for $10 \mathrm{~min}$. The aqueous phase was collected and the remaining phenol was removed by ethyl ether. Sodium acetate was added at a final concentration of $0.3 \mathrm{M}$. Two volumes of cold $95 \%$ ethanol was then added and incubated at $-20 \mathrm{C}$. After $3 \mathrm{hr}$, the precipitated DNA was collected by centrifugation at 7,000 $\times g$ for 10 min and gently dissolved in TES buffer.

To detect the phage DNAs in the specimens thus obtained, agarose gel electrophoresis was carried out. Forty $\mu 1$ of phage DNA suspension was mixed with $10 \mu 1$ of $25 \%$ sucrose containing $5 \mathrm{mM}$ sodium acetate, $0.05 \%$ bromophenol blue and $0.1 \%$ SDS. The mixture was then subjected to a cylindrical ge $1(0.6 \times 15 \mathrm{~cm})$ of $0.7 \%$ agarose dissolved in $\mathrm{E}$ buffer $(40 \mathrm{mM}$ Tris, $20 \mathrm{mM}$ sodium acetate, $2 \mathrm{mM}$ EDTA, adjusted to $\mathrm{pH} 7.8$ with glacial acetic acid). The sample was run at $2.5 \mathrm{~mA} /$ gel. After electrophorsis, gels were stained with ethidium bromide $(0.5 \mu \mathrm{g} / \mathrm{ml})$ and photographed under UV illumination (Kodak technical pan film 2415).

Agarose gel electrophoresis of Xf-DNA isolated by two different methods was shown in Fig. 1. The DNA sample prepared by a modified Clewell and Helinski's method showed three bands (Fig. 1. A). Each band from the top was identified as RFII, single stranded phage DNA and RFI in comparison with the mobility of $\mathrm{Xf}-\mathrm{DNA}$ reported by Dai et al.5) A band of the contaminated bacterial DNA was sometimes detected at the upper position of the top band. DNA sample prepared by a modified Comai and Kosuge's method showed only one band of RFI in the electrophoresis (Fig. 1. B).

\section{Transfection}

Transfection assay was done by the procedure of Mandel and Higa ${ }^{10}$ to examine whether Xf-RFI prepared by the modified Comai and Kosuge's method have the infectivity or not. $\quad X$. campestris pv. oryzae N5850 was grown at $30 \mathrm{C}$ in PS medium to reach an optical density of 0.4 at $660 \mathrm{~nm}$. The bacteria were harvested and washed by centrifugation $(8,000 \times \mathrm{g}, 10 \mathrm{~min})$ in $10 \mathrm{mM} \mathrm{NaCl}$. Bacterial pellet was resuspended

Table 1. Transfection of Xf-RFI

\begin{tabular}{lc}
\hline \multicolumn{1}{c}{ Experiments } & PFU $/ \mathrm{ml}$ \\
\hline Competent cells $+\mathrm{Xf}-\mathrm{RFI}$ & $1.2 \times 10^{2}$ (transfectants/ml) \\
Competent cells $+\mathrm{Xf}-\mathrm{RFI}$ (DNase treated) & 0 \\
$\mathrm{Xf}-\mathrm{RFI}$ & 0 \\
Competent cells & 0 \\
\hline
\end{tabular}


in one half of the original volume of chilled $0.03 \mathrm{M} \mathrm{CaCl}_{2}$ solution and kept at $0 \mathrm{C}$ for 20 min. The bacteria were then centrifuged at $8,000 \times g$ for $5 \mathrm{~min}$, and resuspended in $1 / 10$ of the original volume of $0.03 \mathrm{M} \mathrm{CaCl}_{2}$ solution. $0.2 \mu \mathrm{l}$ of the competent cells treated with $\mathrm{CaCl}_{2}$ was added to $1 \mu 1$ of $\mathrm{Xf}-\mathrm{RFI}$ and incubated at $0 \mathrm{C}$ for $30 \mathrm{~min}$. The bacteria were then subjected to a heat pulse at $37 \mathrm{C}$ for 5 min. The mixture was plated with $X$. campestris pv. oryzae N5850 for plaque formation.

As shown in Table 1, transfection was successful. If the conditions for transfection could be improved, the efficiency might be increased.

\section{Molecular weight of Xf-and Xf 2-RIF}

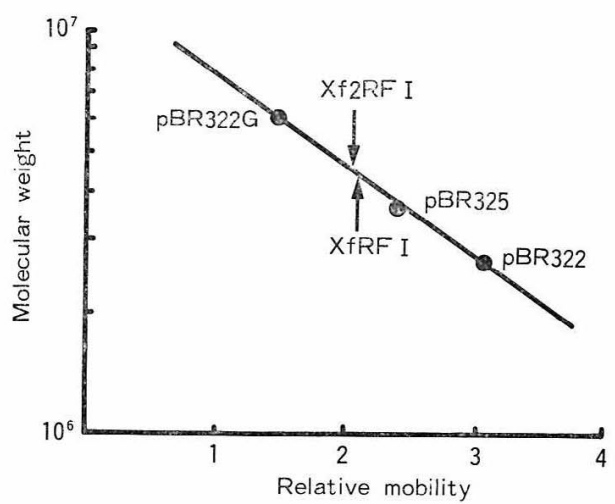

Fig. 2. Molecular weights of Xf- and Xf2-RFI. Both samples estimated from relative mobilities in comparison with those of the standard plasmid DNAs from E. coli.

pBR 322 (2.6 Mdal), pBR 325 (3.6 Mdal), pBR 322G (6.1 Mdal)

Agarose slab gel (1\%) was used for estimation of molecular weight by electrohorpesis. The molecular weight of Xf-and

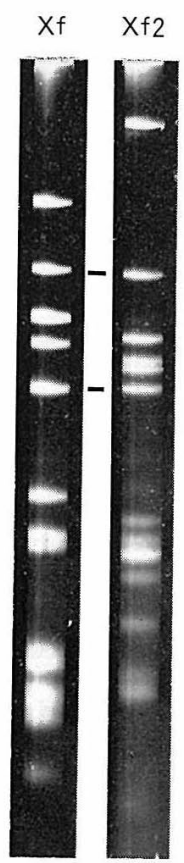

Hpa II

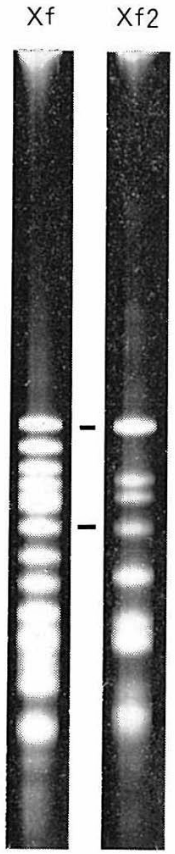

Hha I

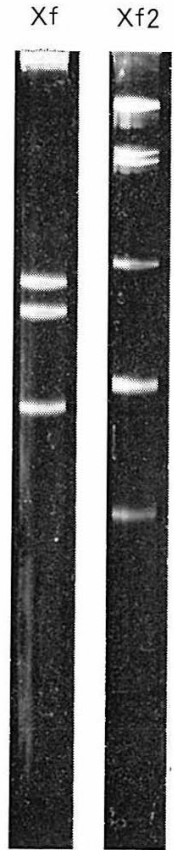

Hind II

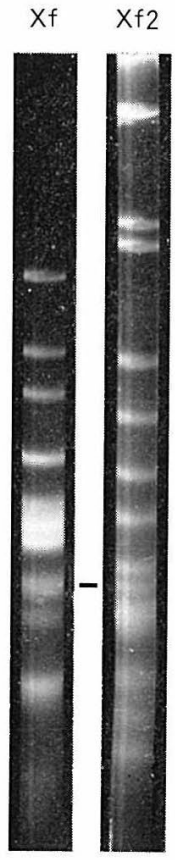

Hae II
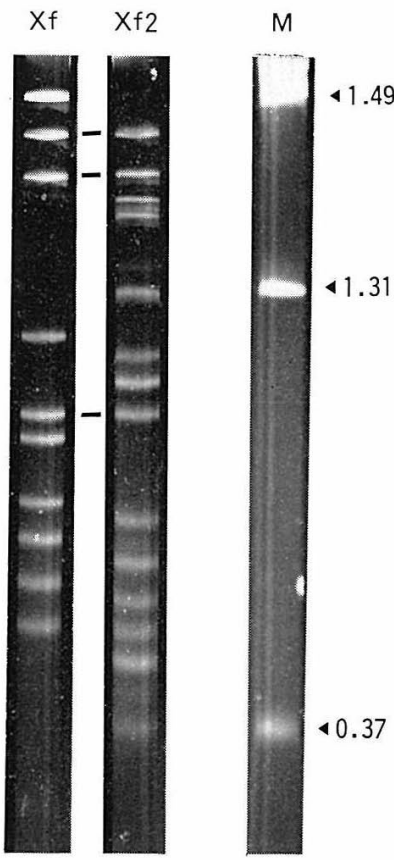

Alu I

Fig. 3. Gel electrophoretic patterns of Xf- and Xf 2-RFI digested with restriction endonucleases. M : Marker [Lambda DNA digested with Hind III. Numbers indicate molecular weight (Mdal)].

The bars indicate DNA fragments showing similar mobility. 
Xf 2-RFI was estimated by comparing their relative mobilities with those of standard plasmids pBR 322 (2.6 Mdal), pBR 325 (3.6 Mdal) and pBR $322 \mathrm{G}$ (6.1 Mdal) (Fig. 2). The molecular weight of Xf 2-RFI was calculated at $4.7 \times 10^{6}$ daltons, and it was slightly larger than that of Xf-RFI $\left(4.5 \times 10^{6}\right.$ daltons $)$.

\section{Electrophoresis patterns of Xf-and Xf 2-RFI digested with endonucleases}

For complete digestion, $1 \mu \mathrm{l}$ of RFI was incubated for $2 \mathrm{hr}$ at $37 \mathrm{C}$ in $49 \mu \mathrm{l}$ of digestion buffer ( $10 \mathrm{mM}$ Tris- $\mathrm{HCl}, \mathrm{pH} 7.6,7 \mathrm{mM} \mathrm{MgCl}_{2}, 7 \mathrm{mM}$ mercaptoethanol) containing appropriate amounts of restriction endonucleases of Hpa II, Hha I, Hind II, Hae III and Alu I. The reaction was terminated by the addition of $15 \mu \mathrm{l}$ of a solution containing $0.2 \mathrm{M}$ EDTA, $75 \%$ sucrose and $0.1 \%$ bromophenol blue. The reaction mixture was then subjected to cylindrical gels $(0.6 \times 14 \mathrm{~cm})$ of $4 \%$ polyacrylamide, $0.2 \%$ $\mathrm{N}, \mathrm{N}^{\prime}$-methylenebisacrylamide, 0.001 volume of $\mathrm{N} \mathrm{N} \mathrm{N}^{\prime} \mathrm{N}^{\prime}$-tetramethylethylenediamine and $0.1 \%$ ammonium persulfate in $\mathrm{E}$ buffer. Electrophoresis was carried out at $5 \mathrm{~mA}$ per gel. After electrophoresis, the gels were stained with ethidium bromide solution $(2 \mu \mathrm{g} / \mathrm{ml})$ and photographed in short UV light. Molecular weight of DNA fragments detected in this experiments ranged from 1.49 to $0.37 \mathrm{Mdal}$.

As shown in Fig. 3, the electrophoresis patterns of Xf-and Xf 2-RFI digested with five different restriction enzymes were considerably different. When Xf-and Xf 2-RFI were digested with Hpa II, Hha I, Hae III and Alu I, one to three DNA fragments showed similar mobility. Cleavage products by Hind II, however, none of the fragment appeared showing similar electrophoretic mobility. From these results, it will be concluded that phage Xf and Xf 2 were fundamentally heterogeneous.

The authors wish to express their appreciation to Dr. T. Miki, Faculty of Pharmaceutical Sciences, Kyushu University, for his kind supply of plasmids.

\section{Literature cited}

1. Casse, F., Bouher, C., Julliot, J. S., Michel, M. and Denarie, J. (1979). J. Gen. Microbiol. 113: 229-242.

2. Clewell, D. B. and Helinski, D. R. (1969). Proc. Natl. Acad. Sci. USA 62 : 1159-1166.

3. Comai, L. and Kosuge, T. (1982). J. Bacteriol. 149: 40-46.

4. Currier, T. C. and Nester, E. W. (1976). Anal. Biochem. 76: 431-441.

5. Dai, H., Chiang, K-S. and Kuo, T-T. (1980). J. gen. Virol. 46: 277-299.

6. Humphreys, G. O., Willshaw, G. A. and Anderson, E. S. (1975). Biochim. Biophys. Acta. 383 : 457-463.

7. Kamiunten, H. and Wakimoto, S. (1979). Ann. Phytopath. Soc. Japan 45: 174-184.

8. Kamiunten, H. and Wakimoto, S. (1980). Ibid.46:315-321.

9. Kupersztoch-Portnoy, Y. M., Lovett, M. A. and Helinski, D. R. (1974). Biochemistry 13: 54845490.

10. Mandel, M. and Higa, A. (1970). J. Mol. Biol. 53 : 159-162.

11. Van den Hondel, C. A. and Schoenmakers, J. G. G. (1976). J. Virol. 18: 1024-1039.

12. Wakimoto, S. (1969). Tropical Agr. Res. Ser. No. 1., Agriculture, Forestry and Fisheries Council, Tokyo. pp. 19-24.

13. Wakimoto, S., Katsuki, Y., Matsuo, N. and Kamiunten, H. (1979). Ann. Phytopath. Soc. Japan $45: 168-173$. 
和文摘要

繊維状ファージ Xf 特よび Xf 2 の複

製型 DNAの制限酵素による切断

上運天 博 ・脇本 哲

イネ白葉枯病菌絨維状ファージ Xf おっよ゙ Xf 2 の DNA 塩基組成は極めて類似している。それら両フ アージの複製型 DNA (RFI-DNA) を各種の制限酵素によって切断し, DNA 断片の泳動パターンを比較し, 両者の類縁の程度を検討した。RFI-DNA はファージ感染菌の溶菌液からエタノール沈殿により調製した。 得られた RFI はイネ白葉枯病菌に対し感染性を有していた。Xf-RFI 拈よび Xf 2-RFI の分子量はアガロ 一スゲル電気泳動の相対移動度より, それぞれ $4.5 \times 10^{6}$ 拈よび $4.7 \times 10^{6}$ ダルトンと推定された。両ファー ジの RF-I を制限酵素 Hpa II, Hha I, Hind II, Hae III, Alu I で処理し，ポリアクリルアミドゲル電気 泳動にかけた結果, 得られた切断パターンには同一の泳動度を示す断片は極めて少なく，Xf および Xf 2 は かなり異なったファージであることが明らかとなった。 